Article

\title{
The Effect of Firm Life Cycle on the Relationship between R\&D Expenditures and Future Performance, Earnings Uncertainty, and Sustainable Growth
}

\author{
Jiyeon Yoo ${ }^{1}$, Sangryul Lee ${ }^{2, *}$ and Sambock Park ${ }^{2}$ \\ 1 College of Economics and Business Administration, Sangji University, 83 Sangjidaegil, Wonju-si, \\ Gangwon-do 26339, Korea; yoojiyeon@sangji.ac.kr \\ 2 College of Business and Economics, Hanyang University Erica, 55 Hanyangdaehak-ro, Sangnok-gu, \\ Ansan-si, Gyeonggi-do 15588, Korea; psp96@hanyang.ac.kr \\ * Correspondence: berg7600@hanyang.ac.kr
}

Received: 17 March 2019; Accepted: 17 April 2019; Published: 20 April 2019

\begin{abstract}
R\&D investment can reduce costs through efficient production technology, which has a positive (+) impact on future performance. On the other hand, R\&D investment has uncertainty due to characteristics such as time lag, high cost and non-appropriability. We examine whether the effects of R\&D expenditures on future performance and earnings uncertainty are different according to firm life cycle, which reflects the differences in the environment, circumstances, and strategy of the firm. Investors assess sustainable growth potential of the enterprise in the capital market, reflecting the future performance and the uncertainty of the firm. This implies that R\&D investment can affect the capital market through investors' future expectations for sustainable growth of the company. We also examine the differential effects of R\&D expenditures on market response by the firm life cycle. The test results show that firm life cycle differentially affects the relation between R\&D expenditures and future performance and uncertainty. Further, the market response varies over the firm life cycle. Our results provide suggestions that R\&D investments should be made properly considering the environment and circumstances of the firm. The finding that R\&D expenditures differently affect future performance, uncertainty, and sustainable growth potential according to the firm life cycle is expected to help managers make decisions about R\&D investment.
\end{abstract}

Keywords: R\&D expenditures; firm life cycle; future performance; earnings uncertainty; market response

\section{Introduction}

Firms are striving to secure core competencies for maximizing firm value through sustainable growth. Recently, R\&D investment has been regarded as an important factor in securing core competencies for survival in the rapidly changing business environment. Aghion and Howitt (1992) [1] argue that even with the input of the same production factors, firms that have the knowledge to operate and apply them can create higher firm value. Since this knowledge can be acquired through $R \& D$ expenditures, $R \& D$ investment is becoming a core strategy of the firm. Sustainable growth potential should be secured in the long term by pursuing growth strategies based on technological innovation. To this end, efforts to increase R\&D investment and deepen technological advancement should be expanded.

Chun et al. (2014) [2] report that R\&D investment directly affects future profitability as it enables production of new products and development of new technologies. R\&D investment can also reduce costs through efficient production technology, which has a positive (+) impact on future performance. 
On the other hand, R\&D investment has uncertainty, which means that the effects of R\&D investment are not always positively affecting the firm value [3]. In other words, if R\&D investment fails, sunk costs will increase, which can negatively affect the firm value. Researchers have examined the effects of $R \& D$ investment on future management performance. In relation to future performance, many studies provide evidence showing that R\&D investment is positively associated with future performance [4-6]. However, some studies report that R\&D investment has no or minimal negative impact on future performance $[7,8]$.

Meanwhile, Kothari et al. (2002) [9] provide evidence that R\&D investment has greater future uncertainty than investment in tangible assets. Amir et al. (2007) [10] also provide evidence that in industries with high $R \& D$ intensity, R\&D investment has greater future uncertainty than investment in tangible assets, while in industries with low R\&D intensity there is no difference between the two.

In previous studies mentioned above, R\&D investment may vary depending on the environment and circumstances and strategies chosen by the firm [11]. Therefore, we are interested in considering the differences in the environment and circumstances of the firm.

In the theory of firm life cycle, firms are known to show differences in management environment, organizational structure, and strategy by life cycle stage [11-14]. Therefore, we examine whether the effects of $R \& D$ expenditures on future performance and earnings uncertainty are different according to firm life cycle which reflects the differences in the environment, circumstances, and strategy of the firm. In addition, investors evaluate firm's sustainable growth potential in the capital market, reflecting the future performance and uncertainty of the firm. This implies that R\&D investment affects the capital market through investors' future expectations for firm's sustainable issue. So, we also examine whether the effects of $R \& D$ expenditures on market response are different according to firm life cycle. We showed a comprehensive view of the response to capital markets through the effects of R\&D investment on future performance, uncertainty and sustainable growth. In prior studies, the relationship between $R \& D$ investment and future performance, uncertainty, and capital market response has been analyzed individually.

We divide a firm life cycle into four stages: introduction, growth, maturity, and decline, using cash flow patterns of Dickinson (2011) [14]. Further, we use samples of Korean firms which are suitable for investigating the effects of R\&D investment outside of advanced countries such as the U.S. Korea is one of well-developed countries with capital markets and global business players, and many firms are investing heavily in R\&D.

The remainder of our paper proceeds as follows: Section 2 contains the prior studies and hypothesis development. Section 3 contains empirical models, measurement of variables and sample. Section 4 provides the empirical results of our study. Finally, Section 5 contains some conclusions and limitations.

\section{Literature Review and Research Hypotheses}

\subsection{RED Investment and Firm Performance}

Researchers have examined the effects of R\&D expenditures on firm performance. Previous studies that investigate the effects of $R \& D$ expenditures on firm performance show conflicting results. Chauvin and Hirschey (1993) [15] argue that firms pursue technology innovation through R\&D investment, which leads to revenue generation through new product development and positively affects profitability. They also argue that R\&D investment has a positive impact on the profitability of the firm by improving production efficiency due to cost reduction. Bublitz and Ettredge [4] also argue that R\&D expenditures increase firm's innovation activities, which has a positive (+) impact on sales growth. Lejarraga and Martinez-Ros (2014) [16] argue that decision-making style during the $R \& D$ process depends on firm size, and that decision-making style ultimately affects the scale and quality of the innovative output.

In the Korean capital market, researchers examine the relationship between $R \& D$ expenditures and business performance. They provide evidence that there is a positive $(+)$ relationship between 
R\&D expenditures and business performance. On the other hand, Choi and Kim (2011) [8] divide $R \& D$ expenditures into capitalized R\&D expenditures and costed R\&D expenditures. They find that capitalized R\&D expenditures have a negative (-) impact on future profit growth. Lee and Lee (2009) [7] examine the relationship between R\&D investment and financial performance in the IT service industry. They find that R\&D investment and financial performance do not show a significant relationship.

Many previous studies provide evidence showing that R\&D expenditures are positively associated with corporate performance [5,17-19], but there are studies that $R \& D$ expenditures have negative or no impact on corporate performance $[7,8]$. In prior studies, the reason why $R \& D$ investment had a conflicting effect on firm performance is that the internal and external determinants of R\&D productivity differ among the firms under study.

\subsection{RED Investment and Earnings Uncertainty}

In prior studies, R\&D expenditures have implied future uncertainty $[3,9,20]$, and some studies have shown that uncertainty of R\&D expenditures can vary depending on the situation and environment of the firm [10,21]. Kay (1988) [3] describes four key characteristics of R\&D investment. They are called time lag, costliness, uncertainty, and non-appropriability. The time lag means that the effect of R\&D investment does not appear instantly but appears at a certain time lag. Costliness means that $R \& D$ requires a lot of funds. So, firms need to finance the necessary funds for continuous R\&D investment. Uncertainty means that if the R\&D investment fails, the amount spent on the investment becomes the sunk costs, which is a great burden on the firm. If the size of a firm is small, the negative impact of investment failure can be more significant. Non-appropriability means that one technology can be created or applied to another. This indicates that R\&D investment affects not only technological innovation but also imitation activities of competitors. In other words, the outcome of innovation through R\&D investment has a spill-over effect between industries or within industries.

Kothari et al. (2002) [9] examine the effect of investment in R\&D and tangible assets on earnings volatility as a proxy for future uncertainty. They find that both $R \& D$ and tangible investment have a positive (+) relationship with earnings volatility. They also find that R\&D investment has more uncertainty than tangible investment. In the Korean capital market, researchers examine the relationship between R\&D investment and future uncertainty. They provide evidence that there is a positive $(+)$ relationship between R\&D investment and future uncertainty [18,22].

As mentioned above, the uncertainty of R\&D investment can vary depending on the situation and environment of the firm. Amir et al. (2007) [10] carried out the study by dividing the industries into high-technology industries and low-technology industries, predicting that the effect of investment in $R \& D$ and tangible assets on the earnings volatility can vary depending on the industries. They find that investment in high-technology industries has a greater impact on earnings volatility than low-technology industries. Also, they find that the difference of earnings volatility between tangible assets investment and R\&D investment in the high-technology industries became more apparent. This indicates that the uncertainty of R\&D investment can vary depending on the industries. Yoo (2017) [21] examines the effect of R\&D investment on future earnings volatility by dividing the firms into leader-firms and follower-firms. She finds that the R\&D investment of the leader-firms has a greater impact on future earnings volatility than the follower-firms. This seems to be due to the fact that the leader-firms are engaged in innovative $R \& D$ activities while the follower-firms are carrying out $R \& D$ activities for imitation.

\subsection{RED Investment and Market Response}

In prior studies, studies on the relationship between R\&D investment and market response can be divided into studies on value relevance and earnings response coefficient (hereafter ERC). Researchers measure value relevance using stock price or stock returns. The stock price has a problem of heteroscedasticity due to the difference of firm size, but stock returns are widely used in the study of value relevance because it has the advantage of mitigating the heteroscedasticity. They argue that 
the effect of R\&D investment on value relevance can vary depending on the circumstances of the firm [22-24]. Ho et al. (2006) [23] argue that firms with high growth rates, large size, and low risk have high value relevance of R\&D investment because they can secure funds easily. Lee (2010) [24] finds that firms with high growth rates and easy access to external funding can continue to invest in $R \& D$, which has a positive (+) effect on business performance. In a study by Chung and Park (2016) [22], firms with high uncertainty show greater earnings persistence and growth due to R\&D investment than those with low uncertainty. This suggests that R\&D investment of firms with high uncertainty plays a role to continuously grow earnings.

The earnings response coefficient (ERC) is measured using the stock price response to unexpected earnings. The ERC is widely used to study the market reaction to firm's financial information. Liu and Thomas (2000) [25] argue that ERC is used as a measure of the usefulness of accounting information, in particular as a measure of the value relevance of earnings and earnings quality. In prior studies, researchers mainly studied factors that affect ERC. They find that firms with high earnings persistence have higher ERC [26,27]. And the earnings persistence is supported by sustainable growth potential of the company. This can be interpreted as a result of information on the earnings quality reflected in the capital market. In addition, other studies show that firms with higher debt ratios have lower ERC than those with lower debt ratios [28], and firms with high scores from financial analysts have higher ERC than those with low scores from financial analysts (Imhoff, [29]. In the Korean capital market, Lee (2013) [30] examines the relationship between firm life cycle and ERC, expecting that the firm's earnings quality will differ according to the firm life cycle. He finds that ERC at maturity stage is higher than that at other stages, and argue that ERC is determined by earnings persistence rather than earnings growth and earnings management. Based on the results of prior studies, it is judged that ERC can be used as a proxy to measure the degree of effect of R\&D investment on market response.

\subsection{Firm Life Cycle}

Previous studies on the firm life cycle can be broadly divided into studies on measures of firm life cycle and those on the effect of firm life cycle on specific dependent variables. In the literature of firm life cycle, firms are known to show differences in management environment, organizational structure, and strategy by life cycle stage [11-14]. Anthony and Ramesh (1992) [13] employ the four variables of dividend payout, sales growth rate, capital expenditure, and firm age to distinguish four stages of firm life cycle: introduction, growth, maturity, and decline. Dickinson (2011) [14] identifies each stage of the firm life cycle based on cash flow. He distinguishes five stages of firm life cycle: introduction, growth, maturity, renewal, and decline through the combination of the three cash flow (operating activities, investing activities, and financing activities) patterns.

The characteristics of four stages of firm life cycle are summarized as follows. The introduction stage is a time when firms first enter the market, and there is a high uncertainty and risks in the business. This stage is also a time to invest a lot for future growth. The growth stage is a time when firms grow and competitors emerge. This stage requires a strategy to survive the competition, and is also a time when innovation activities take place. The mature stage is a time when competition is fierce, and firm's sales and business expansion are stagnant. So, this stage is a time when firms need to be more discriminating to get out of competition. Finally, the decline stage is a time when the growth of industry stagnates or declines. This stage is the time when firms are pursuing a withdrawal or recovery strategy [12-14].

Meanwhile, previous studies analyzing the effect of firm life cycle examine the effect of the characteristic of each stage of it on the dependent variables. Dependent variables include various topics such as value relevance, profitability, accruals, earnings management behavior, conservatism, cost stickiness, and management control systems. Adizes (1979) [11] has analyzed R\&D behaviors of firms at different organizational life cycle stages. Kwon and Moon (2009) [31] examine whether the effects of return on equity (ROE) and its components on future profitability and value relevance depend on the firm life cycle. They find that the usefulness and value relevance of current profitability 
at growth stage are lower than those at mature stage, while the usefulness and value relevance of current profitability at decline stage are higher than those at mature stage. Park and Park (2010) [32] find that earnings persistence, $\mathrm{ROE}$, and value relevance of accounting earnings at mature stage are higher than those at growth (or decline) stage, and financial risk and value relevance of net asset at mature stage are lower than those at growth (or decline) stage. Some studies provide empirical evidence that firms manage the earnings downward at the growth and mature stage, and manage the earnings upward at the decline stage [33,34]. Also, Kim and Yang (2012) [35] provide evidence that the growth stage has greater cost stickiness than the other stages. Based on the results of prior studies, since the situation and environment of the firm are different according to the firm life cycle, the effect of R\&D investment is expected to be different by firm life cycle.

\subsection{Research Hypotheses}

R\&D investment has a positive effect of improving future management performance through technological innovation and new product development [15]. Also, R\&D investment has a negative effect of increasing future uncertainty due to characteristics such as time lag, costliness, and non-appropriability [3]. Many previous studies provide evidence showing that R\&D expenditures are positively associated with corporate performance [5,17-19], but there are studies that $R \& D$ expenditures have negative or no impact on corporate performance $[7,8]$. In previous studies, it appears that $R \& D$ expenditures have a conflicting effect on future performance because researchers did not properly reflect the environment and circumstances of the firms.

In relation to the effect of R\&D expenditures on future management performance, we expect that the situation and environment of the firm will be different according to firm life cycle as follows. The introduction stage is a time when firms first enter the market, and there is a high uncertainty and risks in the business. This stage is also a time to invest a lot for future growth. In other words, since the performance of R\&D investment appears with time lag, the R\&D investment at the introduction stage has characteristics that are difficult to be connected directly with the management performance. The growth stage is a time when the effect of $R \& D$ investment in the introduction stage begins to appear as management performance. The growth stage is a time when firms grow and competitors emerge. Firms in the growth stage seek a strategy to continuously invest in R\&D to improve the potential competitiveness of the firm. The mature stage is a time when competition is fierce, and a firm's sales and business expansion are stagnant. So, this stage is a time when firms need to be more discriminating to get out of the competition. The mature stage is also a time when extra funding is created and the benefits of innovation are increased [36,37]. Therefore, the mature stage can have the strongest effect of R\&D investment. Finally, the decline stage is a time when the growth of industry stagnates or declines. This stage is the time when firms are pursuing a withdrawal or recovery strategy [12-14], so the effect of R\&D investment is minimal.

As discussed above, since the firm life cycle reflects the situation and environment of the firms, the four stages of firm life cycle have a different impact on the relationship between R\&D investment and future performance. Therefore, we set Hypothesis 1 as follows to investigate whether firm life cycle affects differentially the relation between $R \& D$ investment and future performance:

Hypothesis 1 (H1). The effect of RED investment on future management performance will vary by firm life cycle.

Next, we investigate the uncertainty of R\&D investment. Kothari et al. (2002) [9] provide evidence that R\&D investment has greater future uncertainty than investment in tangible assets. Amir et al. (2007) [10] also provide evidence that in industries with high R\&D intensity, R\&D investment has greater future uncertainty than investment in tangible assets, while in industries with low R\&D intensity there is no difference between the two. In previous studies, it appears that R\&D expenditures have a conflicting effect on future uncertainty because researchers did not properly reflect the environment and 
circumstances of the firms. This implies that the uncertainty of R\&D investment may vary depending on the environment and circumstances of the firm.

In the literature of firm life cycle, firms are known to show differences in management environment, organizational structure, and strategy by life cycle stage [11-14]. The uncertainty of R\&D investment in introduction stage is high because the company is entering the market for the first time. In addition, it is the first stage of $R \& D$ investment, and it is expected that the burden of sunk cost in the failure of $R$ \& D investment will be bigger than other life cycle. Growth stage firms are larger than those of the introduction stage firms, and risk of failure to enter the market or invest in $R \& D$ is reduced. Therefore, the future uncertainty of $R \& D$ investment is expected to be small. In the mature stage, securing extra funds is easy, and competition is at its most intense. This is the phase in which innovation is pursued with extra funds to obtain differentiation from competitors [12]. Also, the mature stage is the period when investment for strengthening IPRs is actively carried out. If the investment for strengthening the IPRs is done above the appropriate level, the resources will be wasted and the future profitability will be deteriorated. As a result, corporate $R \& D$ investments are likely to increase future uncertainty if they do not meet the eligibility criteria. The decline stage is not a time to pursue innovation, but rather to maintain existing policies and use recovery and withdrawal strategies. As a result, the uncertainty about the R\&D investment in decline stage is expected to be small.

As discussed above, since the firm life cycle reflects the situation and environment of the firms, the four stages of firm life cycle have a different impact on the relationship between R\&D investment and earnings uncertainty. Therefore, we set Hypothesis 2 as follows to investigate whether firm life cycle affects differentially the relation between $R \& D$ investment and earnings uncertainty:

Hypothesis 2 (H2). The effect of RED investment on earnings uncertainty will vary by firm life cycle.

Finally, we investigate the market response of R\&D investment. Researchers measure market response using stock price or stock returns. They argue that the effect of $R \& D$ investment on value relevance can vary depending on the circumstances of the firm [22-24]. Ho et al. (2006) [23] argue that firms with high growth rates, large size, and low risk have high value relevance of R\&D investment because they can secure funds easily. Lee (2010) [24] finds that firms with high growth rates and easy access to external funding can continue to invest in R\&D, which has a positive (+) effect on business performance. In addition, ERC is widely used to study the market reaction to the firm's financial information. Liu and Thomas (2000) [25] argue that ERC is used as a measure of the usefulness of accounting information, in particular as a measure of the value relevance of earnings and earnings quality.

Meanwhile, the improvement of future performance has a positive (+) relationship with firm value, and the increase of future uncertainty has a negative (-) relationship with firm value. Analysts focus on the sustainable growth when assessing firm's intrinsic value in the capital market. This implies that R\&D investment affects the capital market through investors' future expectations for sustainable issue.

The effect of R\&D investment on future management performance and uncertainty is expected to be different for each stage of the firm life cycle as described in Hypothesis 1 and Hypothesis 2 . The R\&D investment of the introduction period is not easily connected with the performance and it is expected that the sunk cost will be bigger when the R \& D investment fails. As a result, the R\&D investment in introduction period is expected to show negative (-) signs on the market response due to the decrease in future management performance and the increase in uncertainty. The growth stage is the period in which the effect of R\&D investment in the introduction phase begins to appear as business performance. Uncertainty is expected to be small because the risk of failure to enter the market or R\&D investment is reduced compared to the introduction period. As a result, the R\&D investment in the growth period is expected to show a positive (+) sign on market response because the growth of the future management performance and uncertainty are expected to be small. R\&D investment can have a positive impact on future profitability in mature stage. However, if the R\&D investment does not meet the eligibility 
criteria, it is likely to increase future uncertainty. As a result, investment in $R \& D$ in the mature period can be insignificant in terms of market response due to an increase in future management performance and an increase in uncertainty. The decline stage is the period of establishing a business withdrawal or recovery strategy [12-14]. The impact of $R \& D$ investment on future profitability and uncertainty is expected to be minimal. As a result, the effects of R\&D investment on market response are negligible because of the small effect on business performance and uncertainty.

Therefore, we set Hypothesis 3 as follows to investigate whether firm life cycle affects differentially the relation between R\&D investment and market response:

Hypothesis 3 (H3). The effect of RED investment on market response will vary by firm life cycle.

\section{Research Design and Sample Selection}

\subsection{Empirical Models}

\subsubsection{Future Management Performance (H1)}

We set up the empirical model (1) to examine the influence of firm life cycle on the relationship between $R \& D$ investment and future management performance. The dependent variable of the empirical model (1) is return on assets $\left(R O A_{t+1}\right)$, which is measured as operating income of $t+1$ divided by total asset of $t$. The model is:

$$
\begin{aligned}
R O A_{t+1}= & \beta_{0}+\beta_{1} R N D_{t}+\beta_{2} L E V_{t}+\beta_{3} B T M_{t}+\beta_{4} S_{I Z E_{t}} \\
& +\beta_{5} A T O_{t}+\beta_{6} R O A_{t}+\sum Y D+\sum I N D+\varepsilon_{t}
\end{aligned}
$$

where $R N D_{t}$ represents the research and development expenditures, which equals the $R \& D$ expense-to-total sales ratio as of the year-end. We measure firm life cycle proxy using the cash flow patterns of Dickinson (2011) [14], and analyze the empirical model by the stage of firm life cycle. The association between R\&D investment and future management performance can be verified using the sign of $\beta_{1}$ in model (1). If the coefficient of $R N D_{t}$ shows a significant positive (+) value, it indicates that R\&D investment positively affects future management performance in the stage of firm life cycle. Conversely, if the coefficient of $R N D_{t}$ shows a significant negative (-) value, it indicates that $R \& D$ investment negatively affects future management performance in the stage of firm life cycle. We expect that the effect of $R \& D$ investment on future management performance will be different for each stage of firm life cycle, so the sign of $\beta_{1}$ will differ for each stage of firm life cycle.

Our study includes numerous control variables associated with future management performance. The debt ratio $\left(L E V_{t}\right)$ is added to the research model to control the financial risk. This equals the total debt-to-total assets ratio as of the year-end. An increase in financial risk has been reported to have a negative (-) impact on future management performance by causing an increase in financial costs. Therefore, the regression coefficient of the debt ratio $\left(L E V_{t}\right)$ will show a negative (-) value. The market value to book value ratio (MTB) is generally used as a measure of growth potential, and MTB is reported to have a positive relationship with future management performance. Since we include book value to market value ratio $\left(B T M_{t}\right)$, which is the reciprocal of $M T B$, as a control variable. $B T M_{t}$ is expected to show a negative (-) relationship with future performance.

Firm size $\left(S I Z E_{t}\right)$ is included to control the influence of firm size, and is measured as the natural $\log$ of total assets [38]. An increase in firm size has been reported to have a positive (+) impact on future performance by causing economies of scale. However, according to the political cost hypothesis, an increase in firm size may produce negative (-) effects due to the cost of various regulations and taxes. Therefore, the association between firm size and future performance is expected to be possible in both directions. Asset turnover $\left(A T O_{t}\right)$ is an indicator of firm activity, and is reported to have a positive (+) relationship with future performance. $A T O_{t}$ equals the total sales-to-lagged total assets ratio. Since corporate profits are sustainable, this year's performance $\left(R O A_{t}\right)$ has a very positive 
$(+)$ association with future performance $\left(R O A_{t+1}\right) \cdot R O A_{t}$ is added to the research model to control earnings persistence and the regression coefficient of $R O A_{t}$ will show a positive $(+)$ value. Finally, yearly and industry dummies are included to control the influence of years and industries on future management performance.

\subsubsection{Earnings Uncertainty (H2)}

We set up the empirical model (2) to examine the influence of firm life cycle on the relationship between R\&D investment and earnings uncertainty. The empirical model (2) is based on the research model of Kothari et al. (2002) [9]. The dependent variable of the empirical model (2) is earnings volatility $\left(V A R_{t+1 \sim t+5}\right)$, and is the standard deviation of operating income, calculated using five annual operating income for year $t+1$ to $t+5$. The model is:

$$
\begin{aligned}
V A R_{t+1 \sim t+5}= & \beta_{0}+\beta_{1} R N D_{t}+\beta_{2} L E V_{t}+\beta_{3} B T M_{t}+\beta_{4} S I Z E_{t}+\beta_{5} R O A_{t}+ \\
& \beta_{6} C A P E X_{t}+\sum Y D+\sum I N D+\varepsilon_{t}
\end{aligned}
$$

where $R N D_{t}$ represents the research and development expenditures, which equals the $R \& D$ expense-to-total sales ratio as of the year-end. We measure firm life cycle proxy using the cash flow patterns of Dickinson (2011) [14], and analyze the empirical model by the stage of firm life cycle. The association between $R \& D$ investment and earnings uncertainty can be verified using the sign of $\beta_{1}$ in model (2). If the coefficient of $R N D_{t}$ shows a significant positive (+) value, it indicates that $R \& D$ investment increases earnings uncertainty in the stage of firm life cycle. Conversely, if the coefficient of $R N D_{t}$ shows a significant negative (-) value, it indicates that R\&D investment decreases earnings uncertainty in the stage of firm life cycle. We expect that the effect of R\&D investment on earnings uncertainty will be different for each stage of firm life cycle, so the sign of $\beta_{1}$ will differ for each stage of firm life cycle.

Our study includes numerous control variables associated with earnings uncertainty. The debt ratio $\left(L E V_{t}\right)$ is added to the research model to control the financial risk. This equals the total debt-to-total assets ratio as of the year-end. An increase in financial risk has been reported to increase future uncertainty by causing an increase in financial costs. Therefore, the regression coefficient of the debt ratio $\left(L E V_{t}\right)$ will show a positive $(+)$ value. The market value to book value ratio (MTB) is also used as a substitute for risk in addition to growth potential, and MTB is reported to have a positive relationship with future uncertainty. Since we include book value to market value ratio $\left(B T M_{t}\right)$, which is the reciprocal of $\mathrm{MTB}$, as a control variable. $B T M_{t}$ is expected to show a negative (-) relationship with future uncertainty.

Firm size $\left(S I Z E_{t}\right)$ is included to control the influence of firm size, and is measured as the natural $\log$ of total assets [38]. An increase in firm size has been reported to have a negative (-) relation with future uncertainty due to stable funding and high levels of diversification. Since corporate profits are sustainable, this year's performance $\left(R O A_{t}\right)$ has a very positive $(+)$ association with future performance $\left(R O A_{t+1}\right) . R O A_{t}$ is added to the research model to control earnings persistence and the regression coefficient of $R O A_{t}$ will show a negative (-) value. In previous studies, the tangible assets investment ratio $\left(C A P E X_{t}\right)$ has been reported to increase earnings volatility due to future uncertainty. Finally, year and industry dummies are included to control the influence of years and industries on earnings uncertainty.

\subsubsection{Market Response (H3)}

We set up the empirical model (3) to examine the influence of firm life cycle on the relationship between R\&D investment and market response. The empirical model (3) is based on Huson et al. (2001) [39]. We employ earnings response coefficient (ERC) to measure the response of capital markets. ERC represents the degree to which abnormal stock returns respond to unexpected earnings, and $\beta_{1}$ in model (3) indicates the ERC. We measure the effect of the R\&D investment on the ERC by adding the 
interaction variables between unexpected earnings and R\&D investment to the model. The dependent variable of the empirical model (3) is size-adjusted stock returns $\left(S A R_{t}\right)$ that equal the buy and hold stock returns from April of period $t$ to March of period $t+1$. The model is:

$$
\begin{gathered}
S A R_{t}=\beta_{0}+\beta_{1} U E_{t}+\beta_{2} U E \times R N D_{t}+\beta_{3} U E \times L E V_{t}+\beta_{4} U E \times B T M_{t}+\beta_{5} R N D_{t}+\beta_{6} L E V_{t}+ \\
\beta_{7} B T M_{t}+\sum Y D+\sum I N D+\varepsilon_{t}
\end{gathered}
$$

where $U E_{t}$ represents unexpected earnings in period $t$, which is equal to the actual earnings for $t$, as reported by TS-2000, less the actual earnings for $t-1 . R N D_{t}$ represents the research and development expenditures, which equals the $R \& D$ expense-to-total sales ratio as of the year-end. We measure firm life cycle proxy using the cash flow patterns of Dickinson (2011) [14], and analyze the empirical model by the stage of firm life cycle. The association between $R \& D$ investment and market response can be verified using the sign of $\beta_{2}$ in model (3). If the coefficient of $U E \times R N D_{t}$ shows a significant positive $(+)$ value, it indicates that $R \& D$ investment increases ERC for unexpected earnings in the stage of firm life cycle. We expect that the effect of R\&D investment on the ERC will be different for each stage of firm life cycle, so the sign of $\beta_{2}$ will differ for each stage of firm life cycle.

Our study includes numerous control variables associated with market response. The debt ratio $\left(L E V_{t}\right)$ is added to the research model to control the financial risk. This equals the total debt-to-total assets ratio as of the year-end. Previous studies have shown that firms with high debt ratios have lower ERC than firms with no debt or low debt ratios [28]. Therefore, the regression coefficient of the debt ratio $\left(L E V_{t}\right)$ will show a negative (-) value. In the case of firms with a high growth potential, investors' response to the net income increases, which increases the ERC. The market value to book value ratio (MTB) is used as a substitute for growth potential, and MTB is reported to have a positive relationship with ERC [40]. Since we include book value to market value ratio $\left(B T M_{t}\right)$, which is the reciprocal of MTB, as a control variable. $B T M_{t}$ is expected to show a negative (-) relationship with ERC. Finally, year and industry dummies are included to control the influence of years and industries stock market return.

\subsection{Measurement of Variables}

\subsubsection{Proxy for Firm Life Cycle}

In previous studies, researchers have used the methodology of Anthony and Ramesh (1992) [13] as a measure of firm life cycle. Anthony and Ramesh (1992) [13] classify firms into firm life cycle using both univariate and multi-variate ranking procedures. They use four classification variables: (1) annual dividend payout (DP), (2) sales growth (SG), (3) capital expenditure divided by value of the firm (CEV), and (4) age of the firm (AGE). However, the method of dividing several variables by quintiles and summing them has a problem of making a constrained assumption about the distribution of each component in the process of constituting the portfolio. Also, this method has the possibility that firm life cycle is randomly classified according to the corporate factors included among various corporate factors. So, Dickinson (2011) [14] point out limitations of Anthony and Ramesh (1992) [13] methodology for measuring firm life cycle and propose to classify firm life cycle using cash flow patterns. Dickinson (2011) [14] divides the cash flow into three types of activities, and then divides the firm life cycle into five categories based on the cash flow patterns of each activity.

Specifically, the introduction stage is expected to be negative (-) for cash flows from operating activities due to the fact that sales are not realized yet, while there is a large amount of expenditure due to expansion of customers and advertisements for building market position. In order to increase market share, it is necessary to invest new investment, so cash flows from investing activities will also have a negative (-) value. And as the borrowing of external funds for these investments, cash flows of financing activities will have a positive (+) value [41]. Next, at the growth stage, sales will increase sharply and cash flows from operating activities will be converted to positive $(+)$ values. On the contrary, cash flows from investing activities is expected to remain negative (-) due to addition facility 
investment in response to rapid sales growth. And cash flows of financing activities are expected to be positive $(+)$ since external financing may be required for facility investment [41]. Third, the mature stage is expected to be positive (+) cash flows from operating activities due to the highest profit level, and negative (-) cash flows from investing activities due to investment for new product development. And financing activities are expected to have negative cash flows as they repay external funding [41]. Fourth, the shake-out stage is known to have no consistent cash flow pattern for each activity. Finally, the decline stage is expected to be negative (-) cash flows from operating activities due to a decrease in sales and profits, and positive (+) cash flows from investing activities due to the disposal of assets rather than new investments. And expectations for the pattern of cash flows from financing activities are not consistent [41].

Dickinson (2011) [14] uses the combination of signs $(+,-)$ of three cash flows (operating activities, investing activities, financing activities) to measure the firm life cycle in five steps as showed in Table 1 below. Among the five stages described above, except for the shake-out stage, we use the four stages of firm life cycle: introduction, growth, mature, and decline.

Table 1. Cash Flow Patterns.

\begin{tabular}{lccccc}
\hline & Introduction & Growth & Mature & Shake-out & Decline \\
\hline Cash flows from operating Activities & - & + & + & $+/-$ & - \\
Cash flows from investing Activities & - & - & - & $+/-$ & + \\
Cash flows from financing Activities & + & + & - & $+/-$ & $+/-$ \\
\hline
\end{tabular}

\subsubsection{Earnings Response Coefficient (ERC)}

Dhaliwal et al. (1991) [28] estimate ERC by using a simple regression model between abnormal stock returns and unexpected earnings. Some studies employ an extended version of the model used in Dhaliwal et al. (1991) [28], namely Collins et al. (1997) [42], Francis and Schipper (1999) [43], Bushman et al. (2004) [44]. Huson et al. (2001) [39] estimate ERC based on a multiple regression model in which abnormal stock returns are regressed on unexpected earnings. The model is defined as follows:

$$
\begin{gathered}
S A R_{t}=\alpha_{0}+\beta \times U E_{t}+\varepsilon_{t} \\
\beta=\beta_{1}+\beta_{2} R N D_{t}+\beta_{3} L E V_{t}+\beta_{4} B T M_{t}+\beta_{5} S_{Z I Z E_{t}}+\varepsilon_{t}
\end{gathered}
$$

In model (4), $\beta$ represents ERC for the unexpected earnings, and model (5) describes the factors that influence ERC $(\beta)$. In prior studies, the factors affecting ERC include debt ratio $\left(L E V_{t}\right)$, firm size $\left(S I Z E_{t}\right)$, and the book value to market value $\left(B T M_{t}\right)$. We add R\&D investment as a factor affecting ERC. R\&D investment affects investor's expectations for future management performance and uncertainty, which also affects ERC. We combine models (4) and (5) to introduce interactions between $U E_{t}$ and the factors affecting ERC. Thus, a model (6) is derived to test the effects of R\&D investment on the ERC. The multi-collinearity of $U E \times S I Z E_{t}$ variable is very large and excluded from model (6). However, there will be no problem because $S A R_{t}$ variable is size-adjusted stock returns.

$$
S A R_{t}=\beta_{0}+\beta_{1} U E_{t}+\beta_{2} U E \times R N D_{t}+\beta_{3} U E \times L E V_{t}+\beta_{4} U E \times B T M_{t}+\varepsilon_{t}
$$

\subsection{Samples and Data}

The sample used in our study consists of firms in the manufacturing industries listed on the Korea Stock Exchange (KRX) and have a fiscal year ending in December. We collect financial data from FN Data-Guide provided by FN Guide in Korea and TS-2000. Financial firms are excluded because firm's operating characteristics and financial statement accounts are different from manufacturing firms. For comparability, we exclude firms with impaired capital and firms without financial data needed for analysis. We employ the standard deviation of operating income from period $t+1$ to period $t+5$ to measure future uncertainties. Finally, to remove the influence of extreme observations, all continuous 
variables are winsorized at the top and bottom $1 \%$ level. The final sample consists of 3,743 firm-year observations from 2000 to 2010.

The sample of this study consists of 516 firms with financial data for more than 6 years from 2000 to 2010 (time series length $=11$, number of cross sections $=516$ ). Composition of the sample by year (life cycle) is indicated in Table 2 below.

Table 2. The Composition of Sample.

\begin{tabular}{cccccc}
\hline Year & Introduction & Growth & Mature & Decline & Total \\
\hline 2000 & 35 & 76 & 121 & 31 & 263 \\
2001 & 23 & 61 & 146 & 27 & 257 \\
2002 & 19 & 52 & 191 & 38 & 300 \\
2003 & 22 & 78 & 173 & 36 & 309 \\
2004 & 35 & 89 & 178 & 31 & 333 \\
2005 & 39 & 114 & 171 & 28 & 352 \\
2006 & 61 & 101 & 184 & 19 & 365 \\
2007 & 72 & 91 & 186 & 34 & 383 \\
2008 & 100 & 138 & 110 & 37 & 385 \\
2009 & 63 & 122 & 180 & 29 & 394 \\
2010 & 63 & 142 & 166 & 31 & 402 \\
Total & 532 & 1064 & 1806 & 341 & 3743 \\
\hline
\end{tabular}

We performed pooled OLS regression because there is an obstacle for using panel data methodology. In this study, the life cycle of each company is classified based on the time t. For example, to measure the future uncertainty, which is a dependent variable of model (2), we classify the life cycle of the firm based on the time $t$, and calculate the profit of the firm from $t+1$ to $t+5$ to measure volatility. The model (1) and the model (3) also classify the life cycle based on the t-point in the same way.

But, the life cycle of a firm can vary from time to time. For example, a company classified as an introductory phase in $t$ could be transformed into a growth phase in $t+2$. This would impede to build panel data set by the life cycle and could justify using pooled OLS regressions instead of panel data analysis.

There may be a reliability problem if the life cycle of individual firm is changed by year. However, Dickinson (2011) [14] reports that the life cycle of individual firm is highly consistent for consecutive year when using the cash flow pattern.

\section{Empirical Results}

\subsection{Descriptive Statistics and Correlations}

Table 3 summarizes the descriptive statistics for all the variables for the full sample of 3743 firm-year observations. R\&D intensity $\left(R N D_{t}\right)$ is the key variable in this study. The R\&D intensity $\left(R N D_{t}\right)$ has a mean (median) value of $0.017(0.008)$, which is similar to that of the previous studies [3,9]. And the mean of R\&D intensity of firms corresponding to upper $99 \%$ is 0.136 , which shows that some firms are concentrating relatively more capabilities on $R \& D$ expenditures. This implies that $R \& D$ investment may vary depending on the environment and circumstances of the firm. The unexpected earnings $\left(U E_{t}\right)$ has a mean (median) value of $0.088(0.001)$, which indicates that there is no clear trend in earnings change over time. Distribution of debt ratio $\left(L E V_{t}\right)$ is stays stable around the median value of 0.464 . The tangible assets investment ratio $\left(C A P E X_{t}\right)$ has a mean (median) value of 0.387 (0.372), which implies that approximately $39 \%$ of total assets are invested in tangible assets. Standard deviations of the remaining variables except the $S A R_{t}, B T M_{t}$, and $S I Z E_{t}$ variables are not large. And most of the variables do not show a large difference between mean and median, so they do not deviate much from the normal distribution. 
Table 3. Descriptive Statistics.

\begin{tabular}{ccccccccc}
\hline Variable & $\mathbf{N}$ & Mean & Std. & Min & $\mathbf{2 5 \%}$ & Median & $\mathbf{7 5 \%}$ & Max \\
\hline$R O A_{t+1}$ & 3743 & 0.058 & 0.067 & -0.157 & 0.022 & 0.052 & 0.091 & 0.264 \\
VAR $_{t+1}$ & 3743 & 0.051 & 0.068 & 0.006 & 0.019 & 0.032 & 0.055 & 0.373 \\
$S A R_{t}$ & 3743 & -0.055 & 0.563 & -1.382 & -0.024 & -0.105 & 0.026 & 2.334 \\
$R N D_{t}$ & 3743 & 0.017 & 0.024 & 0.000 & 0.002 & 0.008 & 0.096 & 0.136 \\
$U E_{t}$ & 3743 & 0.039 & 0.088 & -0.354 & 0.002 & 0.001 & 0.026 & 0.367 \\
$L E V_{t}$ & 3743 & 0.457 & 0.182 & 0.087 & 0.322 & 0.464 & 0.588 & 0.880 \\
$B_{t}$ & 3743 & 1.781 & 1.371 & 0.205 & 0.817 & 1.409 & 2.320 & 7.245 \\
SIZE $_{t}$ & 3743 & 19.624 & 1.512 & 16.969 & 18.540 & 19.285 & 20.456 & 23.906 \\
$A T O_{t}$ & 3743 & 1.077 & 0.534 & 0.187 & 0.721 & 0.981 & 1.324 & 3.033 \\
CAPEX & 3743 & 0.387 & 0.205 & 0.022 & 0.247 & 0.372 & 0.504 & 0.931 \\
\hline
\end{tabular}

Note: Variables definitions; $R O A_{t+1}$ : return on assets, which is measured as operating income of $t+1$ divided by total assets of $t ; V A R_{t+1 \sim t+5}$ : standard deviation of operating income, calculated using five annual operating income for year $t+1$ to $t+5$; $S A R_{t}$ : size-adjusted stock returns, calculated the buy and hold returns from April of $t$ to March of $t+1 ; R N D_{t}$ : R\&D expense-to-total sales ratio as of the year-end; $U E_{t}$ : unexpected earnings, which equal to the actual earnings for $t$ less the actual earnings for $t-1 ; L E V_{t}$ : the total debt-to-total assets ratio as of the year-end; $B T M_{t}$ : the book-to-market ratio of the equity; $S I Z E_{t}$ : the natural log of total assets; $A T O_{t}$ : the total sales-to-lagged total assets; $C A P E X_{t}$ : the tangible assets investment ratio.

Table 4 presents the Pearson correlations. The dependent variable, $R O A_{t+1}$ shows negative (-) correlations with $R N D_{t}$, but not statistically significant. $V A R_{t+1 \sim t+5}$ reports significant positive $(+)$ correlations with $R N D_{t}$. This means that the greater $R \& D$ expenditures, the more the earnings volatility is increased. The $R O A_{t+1}$ indicates significant positive (+) correlations with $S I Z E_{t}, A T O_{t}, U E_{t}$, and $S A R_{t}$ and significant negative (-) correlations with $L E V_{t}, B T M_{t}, V A R_{t+1 \sim t+5}, C A P E X_{t}$. This means that the larger firm size and asset turnover, the more the future performance is improved and the larger debt ratio and earnings volatility, the more the future performance is getting worse.

Table 4. Correlations among the Variables.

\begin{tabular}{lccccccccc}
\hline & RND & LEV & BTM & SIZE & ATO & VAR & CAPEX & UE & SAR \\
\hline ROA $_{t+1}-0.032$ & -0.167 & -0.138 & 0.170 & 0.215 & -0.266 & -0.266 & 0.146 & 0.104 \\
RND $_{t}$ & -0.125 & -0.210 & 0.025 & -0.183 & 0.105 & -0.163 & 0.032 & -0.013 \\
LEV & & & 0.003 & 0.157 & 0.134 & 0.163 & 0.119 & -0.045 & 0.012 \\
BTM $_{t}$ & & & -0.067 & -0.187 & -0.081 & 0.183 & -0.004 & 0.004 \\
SIZE & & & & -0.060 & -0.100 & 0.181 & 0.019 & 0.161 \\
ATO & & & & & -0.105 & -0.012 & 0.098 & 0.057 \\
VAR $_{t+1 \sim t+5}$ & & & & & & -0.072 & -0.013 & -0.088 \\
CAPEX & & & & & & & 0.004 & 0.052 \\
UE & & & & & & & & & 0.183 \\
\hline
\end{tabular}

Note: This table presents Pearson correlations. Coefficients shown in bold are significant at $p<0.05$ (two-tailed test).

\subsection{Regression Results}

\subsubsection{Results for Future Management Performance (H1)}

In previous studies, R\&D expenditures shows a conflicting effect on future performance and uncertainty because researchers may not properly reflect the environment and circumstances of the firms. We examine whether the effects of $R \& D$ expenditures on future performance and earnings uncertainty are different according to the firm life cycle, which reflects the differences in the environment, circumstances, and strategy of the firm. In addition, investors evaluate firm value in the capital market, reflecting the future performance and uncertainty of the firm. This implies that R\&D investment can affect the capital market through investors' assessment for sustainable issue. So, we also test the differential effects of R\&D expenditures on the market response according to the firm life cycle.

Table 5 presents the empirical results of $\mathrm{H} 1$ on the association between R\&D investment and future management performance. In order to test the differential effect of $R \& D$ investment on future 
performance, we divide the whole sample into four sub-samples by firm life cycle and perform pooled regression analysis. $\mathrm{H} 1$ can be tested using the coefficient of $R N D_{t}$. We expect the coefficient of $R N D_{t}$ in model (1) to be different for each stage.

Table 5. The influence of Firm Life Cycle on the Association between R\&D Investment and Future Management Performance.

\begin{tabular}{|c|c|c|c|c|c|c|c|c|}
\hline \multicolumn{8}{|c|}{$R O A_{t+1}=\beta_{0}+\beta_{1} R N D_{t}+\beta_{2} L E V_{t}+\beta_{3} B T M_{t}+\beta_{4} S I Z E_{t}+\beta_{5} A T O_{t}+\beta_{6} R O A_{t}+\sum Y D+\sum I N D+\varepsilon_{t}$} & (1) \\
\hline \multirow{2}{*}{ Variable } & \multicolumn{2}{|c|}{ Introduction } & \multicolumn{2}{|c|}{ Growth } & \multicolumn{2}{|c|}{ Mature } & \multicolumn{2}{|c|}{ Decline } \\
\hline & Coefficient & $t$-Value & Coefficient & $t$-Value & Coefficient & $t$-Value & Coefficient & $t$-Value \\
\hline Intercept & -0.085 & $-2.29 * *$ & -0.005 & -0.22 & -0.009 & -0.47 & -0.365 & $-7.24^{* * *}$ \\
\hline$R N D_{t}$ & -0.249 & $-2.91 * * *$ & 0.098 & 1.22 & 0.186 & $2.84^{* * *}$ & -0.004 & -0.03 \\
\hline$L E V_{t}$ & -0.011 & -0.67 & -0.022 & $-1.77^{*}$ & -0.027 & $-3.22 * * *$ & -0.032 & $-1.88 *$ \\
\hline$B T M_{t}$ & -0.006 & $-2.41^{* * *}$ & -0.007 & $-4.60 * * *$ & -0.011 & $-10.11^{* *}$ & -0.004 & -1.64 \\
\hline$S I Z E_{t}$ & 0.005 & $2.41^{* *}$ & 0.002 & $2.00^{* *}$ & 0.004 & $3.90 * * *$ & 0.018 & $6.77^{* * *}$ \\
\hline$A T O_{t}$ & 0.018 & $2.80^{* * *}$ & 0.019 & $5.73^{* * *}$ & 0.020 & $7.02 * * *$ & 0.040 & $5.77^{* * *}$ \\
\hline$R O A_{t}$ & 0.506 & $8.90^{* * *}$ & 0.590 & $22.58^{* * *}$ & 0.732 & $39.76^{* * *}$ & 0.506 & $8.90^{* * *}$ \\
\hline Year and Industry Dummy & \multicolumn{2}{|c|}{ Included } & \multicolumn{2}{|c|}{ Included } & \multicolumn{2}{|c|}{ Included } & \multicolumn{2}{|c|}{ Included } \\
\hline Adj. $R^{2}$ & \multicolumn{2}{|c|}{0.231} & \multicolumn{2}{|c|}{0.1737} & \multicolumn{2}{|c|}{0.540} & \multicolumn{2}{|c|}{0.386} \\
\hline $\mathrm{N}$ & \multicolumn{2}{|c|}{532} & \multicolumn{2}{|c|}{1064} & \multicolumn{2}{|c|}{1806} & \multicolumn{2}{|c|}{341} \\
\hline Chow & \\
\hline
\end{tabular}

Note: This table reports the influence of firm life cycle on the association between R\&D investment and future management performance. ${ }^{* * *},{ }^{* *},{ }^{*}$ represent significance at the $0.01,0.05$, and 0.1 level, respectively.

At the introduction stage, $R N D_{t}$ shows negative ( -$)$ and significant $\left(\beta_{1}=-0.249, t=-2.91\right)$ value at the 0.01 level. Since the introduction is the initial stage of market entry, R\&D investment seems to be deteriorating future performance than being fruitful in the short term [13]. The coefficient of $R N D_{t}$ is positive (+) but not significant at the growth stage. And the mature stage shows positive $(+)$ and significant $\left(\beta_{1}=0.186, t=2.84\right)$ coefficient of $R N D_{t}$ at the 0.01 level. Consistent with Fellner (1951) [36] as well as Arrow (1962) [37], the results indicate that the mature is the stage of developing core competencies of the firm. At the Decline stage, the coefficient of $R N D_{t}$ is positive (+) but not significant. In addition, the control variables, $S I Z E_{t}, A T O_{t}$, and $R O A_{t}$ shows significant positive (+) relation with $R O A_{t+1}$, while LEV and BTM indicates a significant negative (-) relation with $R O A_{t+1}$.

We have performed Chow test to verify whether the effect of R\&D investment on the future performance differs over groups of firms at different life cycle stages. For testing hypothesis 1, we have combined four different groups into one pooled data, and have added the interaction terms $(\mathrm{RND} \times$ Introduction, $\mathrm{RND} \times$ Growth, $\mathrm{RND} \times$ Mature $)$ in the pooled model. The last row of Table 5 reports Chow test result ( $F$-value), which shows that the estimated coefficients of RND $\left(\beta_{1}\right)$ over four life cycle groups are not equal at 0.01 level in model (1). In sum, Table 5 reports that the effect of $R \& D$ investment on the future performance differs by firm life cycle and supports H1. In other words, firm life cycle, which reflects the differences in the firm's environment, situation and strategy, has a different impact on the relationship between $R \& D$ investment and future management performance.

\subsubsection{Results for Future Uncertainty (H2)}

Table 6 reports the regression results of $\mathrm{H} 2$ on the association between R\&D investment and future uncertainty. The relationship between $R \& D$ investment and future earnings volatility can be tested using the coefficient of $R N D_{t}$ in model (2). We expect the coefficient of $R N D_{t}$ in model (2) to be different for each stage.

The introduction stage shows positive $(+)$ and significant $\left(\beta_{1}=0.415, t=4.28\right)$ coefficient of $R N D_{t}$ at the 0.01 level. Since the introduction is the initial stage of market entry, R\&D investment seems to be increasing future uncertainty [21]. At the growth stage, the coefficient of $R N D_{t}$ is positive (+) but not significant. The coefficient of $R N D_{t}$ at mature stage is positive $(+)$ and significant $\left(\beta_{1}=0.127, t=2.84\right)$ at the 0.01 level. The coefficient of $R N D_{t}$ at decline stage is positive (+) but not significant. In addition, 
the control variables, $L E V_{t}$ indicates significant positive (+) relation with $V A R_{t+1 \sim t+5}$, while $B T M_{t}$, $S I Z E_{t}$, and $R O A_{t}$ shows a significant negative (-) relation with $V A R_{t+1 \sim t+5}$.

Table 6. The influence of Firm Life Cycle on the Association between R\&D Investment and Future Uncertainty.

\begin{tabular}{|c|c|c|c|c|c|c|c|c|}
\hline \multicolumn{8}{|c|}{$V A R_{t+1 \sim t+5}=\beta_{0}+\beta_{1} R N D_{t}+\beta_{2} L E V_{t}+\beta_{3} B T M_{t}+\beta_{4} S I Z E_{t}+\beta_{5} R O A_{t}+\beta_{6} C A P E X_{t}+\sum Y D+\sum I N D+\varepsilon_{t}$} & (2) \\
\hline \multirow{2}{*}{ Variable } & \multicolumn{2}{|c|}{ Introduction } & \multicolumn{2}{|c|}{ Growth } & \multicolumn{2}{|c|}{ Mature } & \multicolumn{2}{|c|}{ Decline } \\
\hline & Coefficient & $t$-Value & Coefficient & $t$-Value & Coefficient & $t$-Value & Coefficient & $t$-Value \\
\hline Intercept & 0.141 & $3.39 * * *$ & 0.038 & $1.97 *$ & 0.051 & $3.99 * * *$ & 0.223 & $3.93^{* * *}$ \\
\hline$R N D_{t}$ & 0.415 & $4.28 * * *$ & 0.058 & 0.85 & 0.127 & $2.84^{* * *}$ & 0.141 & 1.02 \\
\hline$L E V_{t}$ & 0.055 & $3.12 * * *$ & 0.032 & $3.54^{* * *}$ & 0.038 & $7.40^{* * *}$ & 0.056 & $3.12^{* * *}$ \\
\hline$B T M_{t}$ & -0.007 & $-2.76^{* * *}$ & -0.005 & $-3.71^{* * *}$ & -0.001 & -0.77 & -0.003 & -1.07 \\
\hline$S I Z E_{t}$ & -0.003 & -1.53 & 0.000 & 0.10 & -0.002 & $-2.53 * *$ & -0.008 & $-2.72 * * *$ \\
\hline$R O A_{t}$ & -0.319 & $-7.21^{* * *}$ & -0.112 & $-4.11^{* * *}$ & -0.021 & -1.21 & -0.388 & $-6.72 * * *$ \\
\hline CAPEX $_{t}$ & -0.013 & -1.04 & 0.002 & 0.23 & -0.002 & -0.37 & -0.015 & -0.88 \\
\hline Year and Industry Dummy & \multicolumn{2}{|c|}{ Included } & \multicolumn{2}{|c|}{ Included } & \multicolumn{2}{|c|}{ Included } & \multicolumn{2}{|c|}{ Included } \\
\hline Adj. $R^{2}$ & \multicolumn{2}{|c|}{0.238} & \multicolumn{2}{|c|}{0.070} & \multicolumn{2}{|c|}{0.075} & \multicolumn{2}{|c|}{0.239} \\
\hline $\mathrm{N}$ & \multicolumn{2}{|c|}{532} & \multicolumn{2}{|c|}{1,064} & \multicolumn{2}{|c|}{1,806} & \multicolumn{2}{|c|}{341} \\
\hline Chow & \\
\hline
\end{tabular}

Note: This table reports the influence of firm life cycle on the association between R\&D investment and future uncertainty. ${ }^{* * *}, * *, *$ represent significance at the $0.01,0.05$, and 0.1 level, respectively.

For the verification of hypothesis 2, Chow test has been used to determine whether the effect of R\&D investment on earnings uncertainty varies by firm life cycle. To do this, we have taken into account additional interaction variables (RND $\times$ Introduction, $R N D \times$ Growth, $R N D \times$ Maturity) in the pooled model. The F-value of Chow test in Table 6 shows that the estimated RND coefficients $\left(\beta_{1}\right)$ over groups of firms at different life cycle stages are not equal at 0.01 level in model (2). In sum, Table 6 shows that the effect of R\&D investment on the future earnings volatility differs by firm life cycle and supports $\mathrm{H} 2$.

\subsubsection{Results for Market Response (H3)}

Table 7 shows the empirical results of $H 3$, which examines the association between $R \& D$ investment and market response. We test $\mathrm{H} 3$ using the coefficient of $U E \times R N D_{t}$ in model (3). If the coefficient of $U E \times R N D_{t}$ has a significant positive (+) value, it is interpreted that $R \& D$ investment has a positive (+) effect on the ERC in each life cycle. We expect the sign of $U E \times R N D_{t}$ in model (3) to be different for each stage.

At the introduction stage, the coefficient of $U E \times R N D_{t}$ is negative $(-)$ and significant $\left(\beta_{2}=-0.136\right.$, $t=-2.35)$ at the 0.05 level. This means that R\&D investment at introduction stage has a negative (-) impact on the ERC. In Tables 5 and 6, the R\&D investment of introduction stage deteriorates future management performance and increases uncertainty. As a result, the capital market seems to send a negative (-) signal for the R\&D investment of introduction stage. The coefficient of $U E \times R N D_{t}$ at mature stage is negative (-) but not significant. In Tables 5 and 6, R\&D investment at the mature stage improves future management performance but also increases uncertainty. At the growth and the decline stages, the coefficient of $U E \times R N D_{t}$ is negative (-) but not significant. This is consistent with the results in Tables 5 and 6.

We have verified hypothesis 3 through Chow test. For Chow testing, we have added the interaction terms $(\mathrm{UE} \times \mathrm{RND} \times$ Introduction, $\mathrm{UE} \times \mathrm{RND} \times$ Growth, $\mathrm{UE} \times \mathrm{RND} \times$ Mature $)$ as independent variables in the pooled model. The Chow test result ( $F$-value) in Table 7 indicates that the estimated coefficients of UE $\times$ RND $\left(\beta_{2}\right)$ over different life cycle groups are not equal at 0.01 level in model (3). In sum, the results in Table 6 reports that the effect of R\&D investment on the ERC differs by firm life cycle and supports $\mathrm{H} 3$. 
Table 7. The Effect of Firm Life Cycle on the Association between R\&D Investment and Market Response.

\begin{tabular}{|c|c|c|c|c|c|c|c|c|}
\hline \multicolumn{7}{|c|}{$\begin{array}{c}S A R_{t}=\beta_{0}+\beta_{1} U E_{t}+\beta_{2} U E \times R N D_{t}+\beta_{3} U E \times L E V_{t}+\beta_{4} U E \times B T M_{t}+\beta_{5} R N D_{t}+\beta_{6} L E V_{t}+\beta_{7} B T M_{t}+ \\
\sum Y D+\sum I N D+\varepsilon_{t}\end{array}$} & \multicolumn{2}{|r|}{ (3) } \\
\hline \multirow{2}{*}{ Variable } & \multicolumn{2}{|c|}{ Introduction } & \multicolumn{2}{|c|}{ Growth } & \multicolumn{2}{|c|}{ Mature } & \multicolumn{2}{|c|}{ Decline } \\
\hline & Coefficient & $t$-Value & Coefficient & $t$-Value & Coefficient & $t$-Value & Coefficient & $t$-Value \\
\hline Intercept & 0.280 & 1.32 & 0.097 & 0.74 & -0.074 & -0.81 & -0.154 & -0.72 \\
\hline UEt & 1.350 & $1.73 * *$ & 3.742 & $3.19 * * *$ & 3.295 & $5.03 * * *$ & 0.087 & 0.94 \\
\hline$U E \times R N D t$ & -0.136 & $-2.35^{* *}$ & -0.065 & -1.32 & -0.044 & -1.07 & 0.034 & 0.64 \\
\hline$U E \times L E V t$ & 0.881 & 0.45 & -3.549 & -2.25 ** & -0.768 & -0.87 & 0.155 & 0.11 \\
\hline$U E \times B T M t$ & 0.233 & 0.79 & -0.029 & -0.15 & -0.308 & $-2.53 * *$ & 0.014 & 0.53 \\
\hline$R N D t$ & -0.015 & -2.11 & -0.001 & -0.20 & -0.004 & -1.20 & -0.002 & -0.22 \\
\hline LEVt & -0.219 & -1.04 & 0.067 & 0.47 & 0.099 & 1.14 & -0.072 & -0.39 \\
\hline BTMt & -0.070 & -2.34 & -0.004 & -0.22 & -0.011 & -0.87 & 0.014 & 0.53 \\
\hline Year and Industry Dummy & \multicolumn{2}{|c|}{ Included } & \multicolumn{2}{|c|}{ Included } & \multicolumn{2}{|c|}{ Included } & \multicolumn{2}{|c|}{ Included } \\
\hline Adj. $R^{2}$ & \multicolumn{2}{|c|}{0.037} & \multicolumn{2}{|c|}{0.050} & \multicolumn{2}{|c|}{0.086} & \multicolumn{2}{|c|}{0.118} \\
\hline $\mathrm{N}$ & \multicolumn{2}{|c|}{532} & \multicolumn{2}{|c|}{1064} & \multicolumn{2}{|c|}{1806} & \multicolumn{2}{|c|}{341} \\
\hline Chow & \multicolumn{6}{|c|}{$5.37 * * *$} & & \\
\hline
\end{tabular}

Note: This table reports the effect of firm life cycle on the association between R\&D investment and market response. $* * *, * *,{ }^{*}$ represent significance at the $0.01,0.05$, and 0.1 level, respectively.

\subsection{Additional Tests}

The main test results are consistent with our research hypotheses, suggesting that firm life cycle affects differentially the relation between R\&D expenditures and future performance, uncertainty, and sustainable growth. These results contribute to the relevant literature by providing the evidence of the differential effects of R\&D expenditures according to firm life cycle. The main tests are analyzed by grouping the whole sample by each stage of life cycle. In this section, we conduct a dummy regression analysis using the pooled sample to examine whether the effects of $R \& D$ expenditures on future performance, uncertainty, and sustainable growth vary over the firm life cycle. We set up the models (7)-(9) by adding life cycle dummy variables. The reference dummy variable is the decline stage.

Table 8 provides the dummy regression results for Hypothesis 1 using the pooled sample. The coefficient of $R N D \times I N T R O D U C T I O N_{t}$ is negative $(-)$ and significant $\left(\beta_{2}=-0.175, t=-1.97\right)$ at the 0.05 level, and the coefficient of $R N D \times G R O W T H_{t}$ and $R N D \times M A T U R E_{t}$ is not significant. This indicates that the R\&D investment of the introduction stage has a more negative (-) impact on future performance compared to the decline stage. This is consistent with the OLS regression results reported earlier. Thus, the result in model (7) supports Hypothesis 1.

Table 9 presents the regression results for Hypothesis 2 . The coefficient of $R N D \times I N T R O D U C T I O N_{t}$ is positive $(+)$ and significant $\left(\beta_{2}=0.338, t=2.77\right)$ at the 0.05 level, and the coefficient of $R N D \times$ $G R O W T H_{t}$ and $R N D \times M A T U R E_{t}$ is not significant. This indicates that the R\&D investment of the introduction stage has a more positive (+) impact on future uncertainty compared to the decline stage. This is consistent with the OLS regression results reported earlier. Thus, the result in model (8) supports Hypothesis 2.

Table 10 provides the results for Hypothesis 3. In model (9), the value of $\beta_{3}, \beta_{4}$, and $\beta_{5}$ indicates the differential effects of R\&D expenditures on the ERC by the firm life cycle. The coefficient of $U E \times R N D \times I N T R O D U C T I O N_{t}$ is positive $(+)$ and significant $\left(\beta_{2}=-0.177, t=-1.92\right)$ at the 0.05 level, and the coefficient of $U E \times R N D \times G R O W T H_{t}$ and $U E \times R N D \times M A T U R E_{t}$ is not significant. This means that the R\&D investment of the introduction stage has a more negative (-) impact on the ERC compared to the decline stage. This result is consistent with the OLS regression results reported earlier. Thus, the result in model (9) supports Hypothesis 3. 
Table 8. The Dummy Regression Analysis for the Hypothesis 1.

\begin{tabular}{|c|c|c|}
\hline \multicolumn{3}{|c|}{ 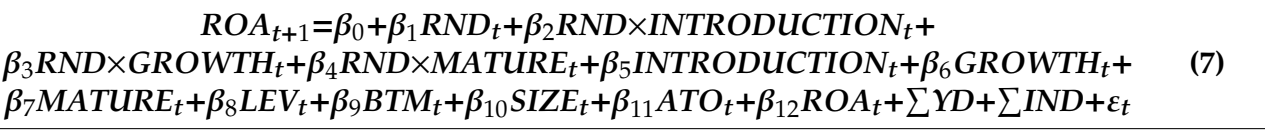 } \\
\hline & Coefficient & $t$-Value \\
\hline Intercept & -0.030 & $-3.40^{* * *}$ \\
\hline$R N D_{t}$ & 0.067 & 0.89 \\
\hline$R N D \times I N T R O D U C T I O N_{t}$ & -0.175 & $-1.97 * *$ \\
\hline$R N D \times G R O W T H_{t}$ & -0.034 & -0.38 \\
\hline$R N D \times M A T U R E_{t}$ & -0.052 & -0.61 \\
\hline INTRODUCTION $_{t}$ & 0.004 & 1.33 \\
\hline GROWTH $H_{t}$ & 0.014 & 1.41 \\
\hline MATURE $_{t}$ & 0.012 & $5.49^{* * *}$ \\
\hline$L E V_{t}$ & -0.001 & -0.27 \\
\hline$B T M_{t}$ & -0.002 & $-3.05 * * *$ \\
\hline$S I Z E_{t}$ & 0.001 & $3.52 * * *$ \\
\hline$A T O_{t}$ & 0.003 & $2.52^{* * *}$ \\
\hline$R O A_{t}$ & 0.670 & $63.22 * * *$ \\
\hline Year and Industry Dummy & \multicolumn{2}{|c|}{ Included } \\
\hline Adj. $R^{2}$ & \multicolumn{2}{|c|}{0.7009} \\
\hline $\mathrm{N}$ & \multicolumn{2}{|c|}{3743} \\
\hline
\end{tabular}

Note: This table reports a dummy regression analysis for the Hypothesis $1 .{ }^{* * *},{ }^{* *},{ }^{*}$ represent significance at the $0.01,0.05$, and 0.1 level, respectively.

Table 9. The Dummy Regression Analysis for the Hypothesis 2.

\begin{tabular}{|c|c|c|}
\hline \multicolumn{3}{|c|}{ 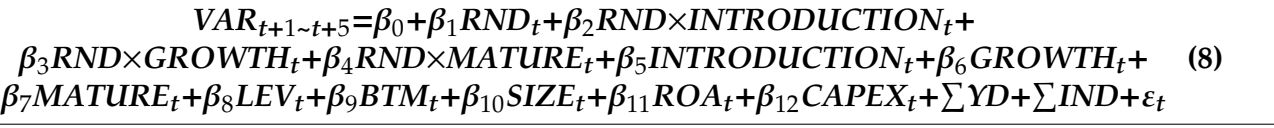 } \\
\hline & Coefficient & $t$-Value \\
\hline Intercept & 0.139 & $10.57^{* * *}$ \\
\hline$R N D t$ & 0.092 & 0.91 \\
\hline$R N D \times I N T R O D U C T I O N t$ & 0.338 & $2.77^{* *}$ \\
\hline$R N D \times G R O W T H t$ & -0.008 & -0.06 \\
\hline$R N D \times M A T U R E t$ & 0.106 & 0.92 \\
\hline INTRODUCTIONt & -0.011 & -2.68 \\
\hline GROWTHt & -0.016 & $-4.02 * * *$ \\
\hline MATUREt & -0.015 & $-3.88^{* * *}$ \\
\hline LEVt & 0.048 & $8.93^{* * *}$ \\
\hline BTMt & -0.006 & $-7.61^{* * *}$ \\
\hline SIZEt & -0.003 & $-4.76^{* * *}$ \\
\hline$R O A t$ & -0.239 & $-14.74^{* * *}$ \\
\hline CAPEXt & -0.010 & $-2.05^{* * *}$ \\
\hline Year and Industry Dummy & \multicolumn{2}{|c|}{ Included } \\
\hline Adj. $R^{2}$ & \multicolumn{2}{|c|}{0.1366} \\
\hline $\mathrm{N}$ & \multicolumn{2}{|c|}{3743} \\
\hline
\end{tabular}

Note: This table reports a dummy regression analysis for the Hypothesis $2 .{ }^{* * *},{ }^{* *},{ }^{*}$ represent significance at the $0.01,0.05$, and 0.1 level, respectively. 
Table 10. The Dummy Regression Analysis for the Hypothesis 3.

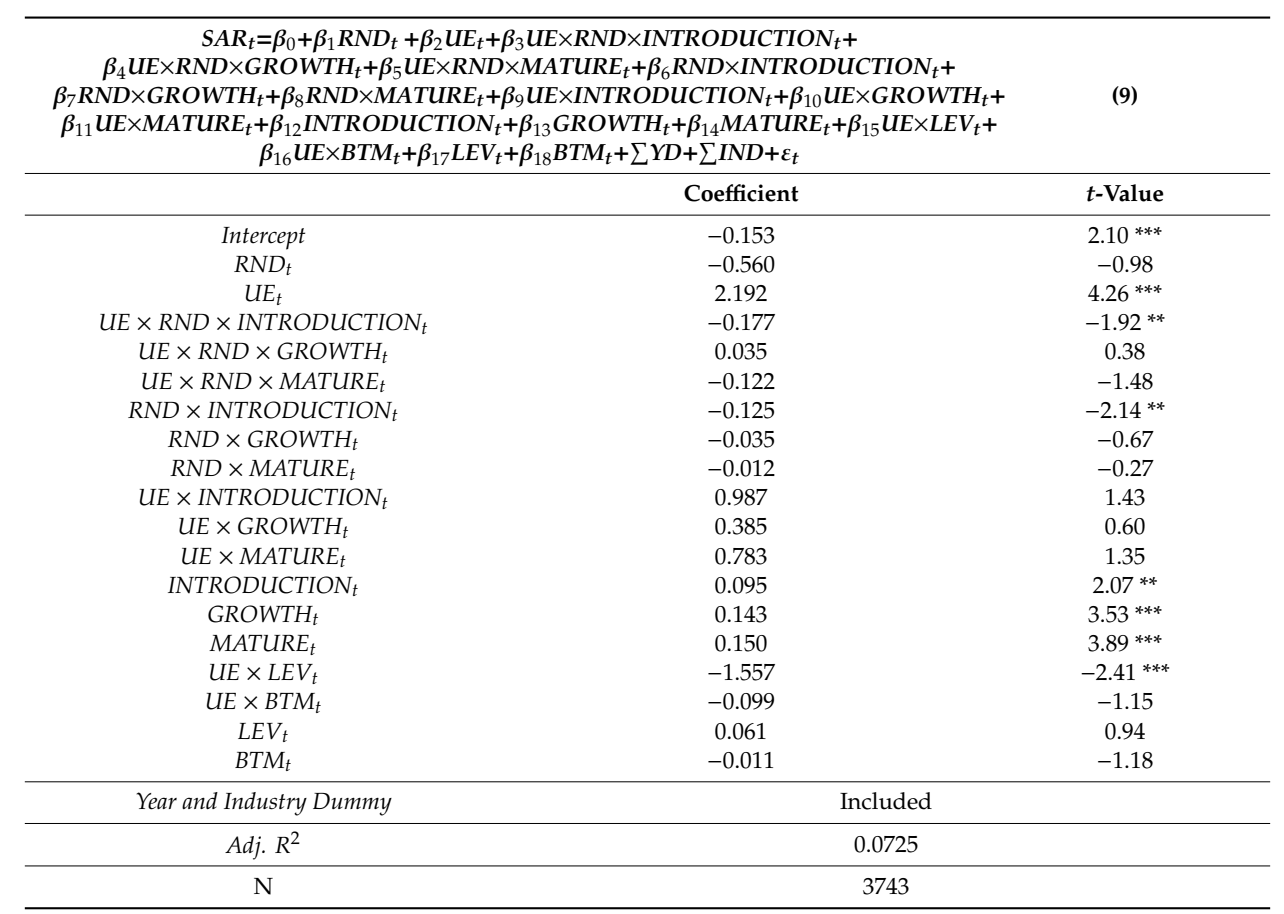

Note: This table reports a dummy regression analysis for the Hypothesis $3 .{ }^{* * *},{ }^{* *},{ }^{*}$ represent significance at the $0.01,0.05$, and 0.1 level, respectively.

\section{Conclusions}

We analyze whether the effects of $R \& D$ expenditures on future management performance, earnings uncertainty and Earnings Response Coefficient (ERC) are different according to firm life cycle. If companies increase their profit by launching innovative new products to the market as a result of R\&D activities, it can be predicted that the increase in net profit will continue for a long period of time. However, if a company gains extraordinary profits by disposing of tangible assets or by discontinuing its business line, it cannot be expected that earnings growth will continue in the next period. The previous studies $[26,27]$ reported that firms with high earnings persistence have higher ERC. This means that earnings persistence of the company should be secured by sustainable growth through R\&D expenditures.

The empirical findings are as follows. First, $R \& D$ expenditures of firms in the introduction stage show a significant negative (-) association with future performance, while R\&D expenditures at the mature stage show a significant positive $(+)$ association with future performance. And there are no statistically significant results in the growth and decline stage. Second, R\&D expenditures show a significant positive $(+)$ association with future uncertainty in both introduction and maturity stages. Meanwhile, there are no statistically significant results in the growth and decline stages. Third, R\&D expenditures of the introduction stage show a significant negative (-) capital market response, and the other stages do not indicate significant results. This means that R\&D expenditures of the introduction stage negatively affect future performance and increase uncertainty, resulting in a significant negative effect on sustainable growth potential. On the other hand, R\&D expenditures of the mature stage have positive effects on future performance and increase uncertainty as well, resulting in insignificant effects on sustainable growth. And the other stages have no significant effects on future performance and uncertainty, so the capital market response for sustainable growth is not significant.

Our results provide the following academic and practical contributions. First, we address the causes of mixed results in prior studies by identifying the different effect of R\&D expenditures by life cycle stages. Second, we provide suggestions that R\&D investments should be made properly considering the environment and circumstances of the firm. When policy authorities and management 
make decisions about R\&D investments, they first need to know which life cycles the company belongs to. In particular, attention should be paid to the R\&D investment of the introduction period because it may cause a negative reaction in the capital market due to deterioration of future sustainable growth potential.

Finally, we show a comprehensive view of the response to capital market through the effects of R\&D investment on future performance, uncertainty and ERC. In prior studies, the relationship between R\&D investment and future performance, uncertainty, and sustainable growth has been analyzed individually.

The limitations of this study are as follows: First, there may be a measurement error in grouping the firm life cycle. Second, there may still be an omitted-related variables problem in the regression model. Third, we have employed OLS regression model without applying panel data analysis. Panel data methodology has the ability to control the unobserved heterogeneity, which is an important factor in the kind of firm decisions or strategies analyzed in this paper.

Author Contributions: Conceptualization, S.L.; Data curation, J.Y.; Formal analysis, J.Y. and S.P.; Methodology, J.Y.; Project administration, S.L.; Writing—original draft, S.P.; Writing—review \& editing, S.L.

Funding: The APC was funded by Hanyang University.

Conflicts of Interest: The authors declare no conflict of interest.

\section{References}

1. Aghion, P.; Howitt, P. A model of growth through creative destruction. Natl. Bur. Econ. Res. 1992, 60, 323-351. [CrossRef]

2. Chun, D.P.; Chung, Y.H.; Bang, S.S. Measuring R\&D productivity of the major Korean firms: Using data envelopment analysis. Korean Acad. Soc. Account. 2014, 19, 173-190.

3. Kay, N.M. The R\&D function: Strategy and structure. Tech. Chang. Econ. Theory 1988, 282-294. [CrossRef]

4. Bublitz, B.; Ettredge, M. The information in discretionary outlays: Advertising, research, and development. Account. Rev. 1989, 64, 108-124.

5. Kim, J.K.; Seo, J.S. The effects of R\&D expenditures on the firm's value. Korean Int. Account. Rev. 2007, 20, 207-229.

6. Chung, A.J.; Park, S.B. The effects of business groups on the association between R\&D intensity and firm's value. Korean Int. Account. Rev. 2014, 57, 38-58.

7. Lee, Y.H.; Lee, H.J. Impact of R\&D expenditure size on financial performance focused on the IT service industry. J. Korea Soc. It Serv. 2009, 8, 1-14.

8. Choi, M.S.; Kim, Y.C. Relation between excess R\&D expenditure and future earnings growth of a firm. Korean Account. Inf. Rev. 2011, 29, 1-28.

9. Kothari, S.P.; Laguerre, T.E.; Leone, A.J. Capitalization versus expensing: Evidence on the uncertainty of future earnings from capital expenditures versus R\&D outlays. Rev. Account. Stud. 2002, 7, 355-382. [CrossRef]

10. Amir, E.; Guan, Y.; Livne, G. The association of R\&D and capital expenditures with subsequent earnings variability. J. Bus. Financ. Account. 2007, 34, 222-246. [CrossRef]

11. Adizes, I. Organizational passages-Diagnosing and treating lifecycle problems of organizations. Organ. Dyn. 1979, 8, 3-25. [CrossRef]

12. Miller, D.; Friesen, P.H. A longitudinal study of the corporate life cycle. Manag. Sci. 1984, 30, 1161-1183. [CrossRef]

13. Anthony, J.H.; Ramesh, K. Association between accounting performance measures and stock prices: A test of the life-cycle hypothesis. J. Account. Econ. 1992, 15, 203-227. [CrossRef]

14. Dickinson, V. Cash flow patterns as a proxy for firm life-cycle. Account. Rev. 2011, 86, 1969-1994. [CrossRef]

15. Chauvin, K.W.; Hirschey, M. Advertising, R\&D expenditures and the market value of the firm. Financ. Manag. $1993,22,128-140$.

16. Lejarraga, J.; Martinez-Ros, E. Size, R\&D productivity and decision styles. Small Bus. Econ. 2014, 42, 643-662. [CrossRef]

17. Hirschey, M.; Weygant, J. Amortization policy for advertising and research and development expenditures. J. Account. Res. 1985, 23, 326-335. [CrossRef] 
18. Sougiannis, T. The accounting based valuation of corporate R\&D. Account. Rev. 1994, 69, 44-68.

19. Cho, S.P.; Chung, J.Y. The effect of R\&D expenditures on subsequent earnings. Korean Manag. Rev. 2001, 30, 289-315.

20. Park, S.K.; Kim, H.G. The uncertainty of future economic benefits from R\&D investments vs capital expenditures. Korean J. Bus. Adm. 2005, 18, 2557-2575.

21. Yoo, J.Y. The effects of R\&D expenditure on the Future Profitability and Earnings Volatility of Leaders and Followers. Ph.D. Thesis, Hanyang University, Seoul, Korea, 2017.

22. Chung, A.J.; Park, S.B. Effects of firm uncertainty on association R\&D expenditure and firm performance: Evidence from Korea. J. Appl. Bus. Res. 2016, 32, 1809-1824.

23. Ho, Y.K.; Tjahjaoranata, M.; Yap, C.M. Size, leverage, concentration, and R\&D investment in generating growth opportunities. J. Bus. 2006, 79, 851-876.

24. Lee, J.G. The effects of firm characteristics on the relationship between R\&D expenditure and corporate value. Korean J. Financ. Eng. 2010, 9, 77-101.

25. Liu, J.; Thomas, J. Stock returns and accounting earnings. J. Account. Res. 2000, 38, 71-101. [CrossRef]

26. Kormendi, B.; Lipe, R. Earnings innovations, earnings persistence, and stock returns. J. Bus. 1987, 60, 323-346. [CrossRef]

27. Easton, P.; Zmijewski, M. Cross sectional variation in the stock-market response to accounting earnings announcements. J. Account. Econ. 1989, 11, 117-141. [CrossRef]

28. Dhaliwal, D.; Lee, K.; Fargher, N. The association between unexpected earnings and abnormal security returns in the presence of financial leverage. Contemp. Account. Res. 1991, 8, 20-41. [CrossRef]

29. Imhoff, J.E. The relation between perceived accounting quality and economic characteristics of the firm. J. Account. Public Policy 1992, 97-118. [CrossRef]

30. Lee, S.Y. Firm life cycle and earnings response coefficient. Korean J. Account. Res. 2013, 18, 179-205.

31. Kwon, S.Y.; Moon, B.Y. Decomposed return on equity, future profitability, and value relevance over the firm life cycle. Korean Manag. Rev. 2009, 39, 1231-1249.

32. Park, W.; Park, S.K. Value relevance of earnings and equity: Role of corporate life cycle. Korean Manag. Rev. 2010, 39, 1451-1476.

33. Koh, Y.S.; Kim, J.S. Analysis on earnings management of managers and corporate life cycle. Account. Inf. Rev. 2012, 30, 163-187.

34. Baik, S.M.; Yang, D.C.; Choi, J.M.; Kim, J.B. Corporate life cycle and real earnings management. Manag. Educ. Rev. 2011, 26, 441-470.

35. Kim, S.R.; Yang, D.H. Corporate life cycle, asymmetric cost behavior and accounting conservatism. Korean J. Manag. Account. Res. 2012, 12, 53-86.

36. Fellner, W. The influence of market structure on technological progress. Q. J. Econ. 1951, 65, 556-577. [CrossRef]

37. Arrow, K. Economic welfare and the allocation of resources for invention. Natl. Bur. Econ. Res. 1962, 609-626. [CrossRef]

38. Francis, J.; LaFond, R.; Olsson, P.; Schipper, K. The market pricing of accruals quality. J. Account. Econ. 2005, 39, 295-327. [CrossRef]

39. Huson, M.R.; Scott, T.W.; Wier, H.A. Earnings dilution and the explanatory power of earnings for returns. Account. Rev. 2001, 76, 602-604. [CrossRef]

40. Collins, D.W.; Kothari, S.P. An analysis of intertemporal and cross-sectional determinants of earnings response coefficients. J. Account. Econ. 1989, 11, 143-181. [CrossRef]

41. Barclay, M.J.; Smith, C.W., Jr. The maturity structure of corporate debt. J. Financ. 1995, 50, 609-631. [CrossRef]

42. Collins, D.W.; Maydew, E.L.; Weiss, L.S. Changes in the value-relevance of earnings and book values over the past forty years. J. Account. Econ. 1997, 24, 39-67. [CrossRef]

43. Francis, J.; Schipper, K. Have financial statements lost their relevance? J. Account. Res. 1999, 37, 319-352. [CrossRef]

44. Bushman, R.; Chen, Q.; Engel, E.; Smith, A. Financial accounting information, organizational complexity and corporate governance systems. J. Account. Econ. 2004, 37, 167-201. [CrossRef] 